\title{
ANALISA FENOMENA ENSO DI PERAIRAN INDONESIA MENGGUNAKAN DATA ALTIMETRI TOPEX/POSEIDON DAN JASON SERIES TAHUN 1993 - 2018
}

\author{
Eko Yuli Handoko ${ }^{1}$, Ragfinsa Budiaski Filaili², Yuwono ${ }^{3}$ \\ 1,2,3 Departemen Teknik Geomatika, FTSLK-ITS, Kampus ITS Sukolilo, Surabaya, 60111, Indonesia \\ e-mail: ${ }^{1}$ ekoyh@geodesy.its.ac.id, ${ }^{2}$ ragfinsa.filaili14@mhs.geodesy.its.ac.id, ${ }^{3}$ yuwono@geodesy.its.ac.id
}

\begin{abstract}
Abstrak
ENSO (EI Nino Oscillation Southern Oscilation) adalah fenomena yang terjadi karena penyimpangan hubungan El Nino Oscillation Southern Oscilation antara laut dan atmosfer sepanjang Samudera Pasifik dari kondisi normalnya.Dampak dari fenomena adalah kekeringan, banjir, pemutihan karang, dan perubahan tinggi muka air laut. Salah satu wilayah yang terdampak El Nino Oscillation Southern Oscilation adalah perairan Indonesia. Untuk menentukan wilayah laut Indonesia yang terpengaruh fenomena El Nino Oscillation Southern Oscilation dilakukan dengan menghitung korelasi antara sea level anomaly dari daa satelit altimetri dengan indeks El Nino Oscillation Southern Oscilation (Multvariate ENSO Index, Southern Oscillation Index, Nino Oscillation Index). Nilai korelasi mean sea level anomaly dengan Multivariate ENSO Index dan Oscillation Nino Index adalah kuat dan negatif. Hasil korelasi mean sea level anomaly dengan Southern Oscilation Index adalah kuat dan positif. Wilayah yang memiliki korelasi kuat antara sea level anomaly dengan indeks ENSO adalah Laut Halmahera, Laut di Utara Papua, Laut Maluku, Laut Sulawesi, dan perairan sekitar Nusa Tenggara Timur. Sedangkan wilayah yang memiliki koreasi lemah ada di perairan sekitar Sumatera, Laut Natuna dan perairan sekitar Jawa bagian barat.
\end{abstract}

Kata kunci : Altimetri, El Nino Southern Oscillation, Sea Level Anomaly, Perairan Indonesia

\begin{abstract}
ENSO (EI Nino Southern Oscillation) is a phenomenon that occurs due to the deviation of the condition of the interaction between oceans and the atmosphere along the Pacific Ocean around the equator from normal state. One of the areas affected by the EI Nino Oscillation Southern Oscilation phenomenon is the Indonesia sea. El Nino Southern Oscillation phenomenon was affected weather and other affected was to the sea level. To find out the territorial Indonesia waters which affected with EI Nino Oscillation Southern Oscilation then performed the calculation of correlation between the value of Sea Level Anomaly from satellite altimetri data with the index ENSO (Multvariate ENSO Index, Southern Oscillation Index, Nino Oscillation Index). The value of the correlation mean sea level anomaly with Multvariate ENSO index and Oscillation Nino Index is strong relation and negative. While correlation mean sea level anomaly with the Southern Oscillation Index is strong relation and positive. The region that have strong relationships of sea level anomaly correlation with ENSO indices are Halmahera sea, sea north of Papua, Maluku sea, Sulawesi sea and sea around East Nusa Tenggara. The area that the correlation low is around of Sumatra, Natuna sea, and sea around West Java.
\end{abstract}

Keywords : Altimetry, El Nino Southern Oscillation, Sea Level Anomaly, Indonesia Sea 


\section{PENDAHULUAN}

ENSO (EI Nino Southern Oscillation) adalah fenomena periodik yang terjadi akibat adanya penyimpangan kondisi interaksi antara lautan dan atmosfer sepanjang Samudera Pasifik sekitar ekuator dari keadaan normalnya sehingga mempengaruhi variabilitas iklim di wilayah ekuator samudera Pasifik dan beberapa bagian bumi. El Nino terjadi ketika suhu permukaan laut di bagian timur Samudera Pasifik meningkat, namun suhu di barat Samudera Pasifik dan sekitar Indonesia mengalami penurunan (penyimpangan) sehingga curah hujan menurun. Hal sebaliknya akan terjadi ketika fenomena La Nina. Untuk mengetahui fenomena ENSO (EI Nino Southern Oscillation) dapat dilihat dari indikator anomali suhu permukaan laut, tekanan udara di atmosfer / Southern Oscillation, dan elevasi permukaan laut (Rejeki, Munasik, \& Kunarso, 2017).

Informasi kelautan tentang perubahan permukaan laut sangat diperlukan diantaranya untuk keperluan pengelolaan dan pengembangan wilayah pesisir, termasuk Indonesia yang merupakan negara kepulauan dimana sebagian besar penduduknya tinggal di pesisir. Posisi Indonesia yang berada di Inter-Tropical Convergence Zone (ITCZ) menyebabkan cuaca / iklim di Indonesia dipengaruhi fenomena ENSO. Pengaruh ENSO berbeda-beda antar wilayah bergantung pada lokasi dan topografi (Qian, Robertson, \& Moron, 2010). ENSO akan mempengaruhi keadaan meteo-oseanografi yaitu kondisi curah hujan di darat maupun laut, suhu permukaan laut, dan tinggi permukaan laut. Perubahan permukaan laut yang positif atau naik akan menyebabkan intrusi air laut ke air permukaan serta tenggelamnya sejumlah kawasan pantai sehingga dapat merusak fasilitas pantai seperti kawasan pelabuhan, pemukiman, dan kawasan perniagaan.

Salah satu dampak dari fenomena ENSO adalah perubahan permukaan laut (sea level anomaly). Pengukuran terhadap perubahan muka air laut awalnya memanfaatkan rambu pasang surut air laut. Seiring dengan kemajuan teknologi akuisisi data saat ini, data elevasi permukaan laut dapat diamati dengan satelit altimetri. Konsep dasar altimetri adalah untuk mengukur jarak dari satelit ke permukaan laut. Satelit altimetri lebih efektif dan efisien digunakan untuk menangani studi dinamika laut secara global dan memiliki kelebihan tidak terbatas oleh kendala cuaca.

Dengan melakukan penghitungan dan analisa sea level anomaly dari data satelit altimetri Topex/Poseidon dan Jason Series didukung dengan data indeks ENSO, diharapkan penelitian ini dapat memberikan gambaran tentang dinamika lautan ketika terjadi ENSO di perairan Indonesia sehingga dapat digunakan untuk monitoring dan studi selanjutya tentang ENSO (EI Nino Southern Oscillation).

\section{METODE}

RADS (Radar Altimetry Database System), dihasilkan oleh Delft Institute for Earth-Oriented Space Research dan NOAA Laboratory for Satelite Altimetry, digunakan pada penelitian ini. Data tersebut berisi hasil pengukuran satelit altimetri dan model koreksi yang harus digunakan pada data altimetri. Pada penelitian ini data yang digunakan adalah dari misi Topex/Poseidon, Jason-1, Jason-2, dan Jason-3 tahun 1993-2018. Data lain yang digunakan pada penelitian ini untuk menentukan kondisi El Nino dan La Nina adalah nilai setiap bulan Multivariate ENSO Index diambil dari website https://www.esrl.noaa.gov/psd/enso/mei/table.html, nilai setiap bulan Oscillation Nino Index dari website http://origin.cpc.ncep.noaa.gov/products/analysis_ monitoring/ensostuff/ONI_v5.php, dan Southern Oscillation Index dari web site http://www.cpc.ncep.noaa.gov/data/indices/soi. Penelitian ini fokus pada wilayah perairan Indonesia yang berada pada rentang $13^{\circ} \mathrm{LU}-20^{\circ} \mathrm{LS}$ dan $90^{\circ}$ BT - $144^{\circ}$ BT Pass (lintasan) dari satelit Topex/Poseidon dan Jason Series yang melewati lokasi penelitian ini sebanyak 44 pass .

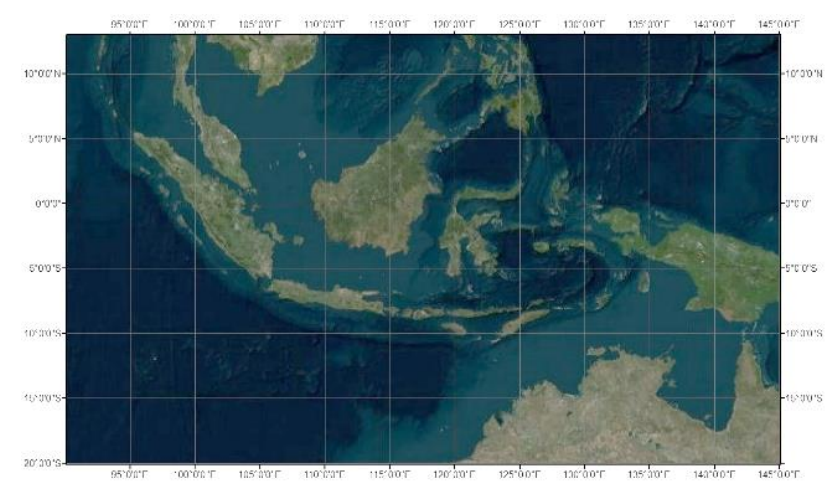

Gambar 1. Lokasi Pengamatan (Google Earth) 
Dalam penelitian ini ada beberapa tahapan yang perlu dilakukan untuk menganalisa SLA di Indonesia terkait fenomena ENSO. Tahapan awal dalam penelitian ini adalah membaca data (.nc) RADS menggunakan perangkat lunak Panoply untuk menentukan parameter yang akan digunakan pada pengolahan data. SLA (Sea level Anomaly) merupakan elevasi permukaan laut di atas geoid / MSS (Mean Sea Surface) oleh karena itu diperlukan parameter altitude, MSS serta model koreksi yang sesuai dan akurat untuk pengolahan data altimetri di wilayah Indonesia. Dalam perhitungan SSH (Sea Surface Height) dan SLA (Sea Level Anomaly) penting dilakukan koreksi karena saat pengambilan data banyak terjadi gangguan. Koreksi yang diperlukan untuk perhitungan SLA adalah dry tropospheric, wet tropospheric, ionospher, sea state bias, dynamic atmospheric, dan tides. Karena penelitian ini menggunakan data multi satelit maka ditambahkan koreksi refrence frame offset (Handoko, Fernandes, \& Lázaro, 2017). Perhitungan SLA diolah menggunakan perangkat lunak MATLAB dengan persamaan (1) dan (2) berikut.

$$
\begin{aligned}
& h_{S L A}=\mathrm{H}-\hat{R}-\Delta \text { RGeo }_{\text {corr }}-M S S \\
& \Delta \text { RGeo }_{\text {Corr }}=\left(\Delta h_{\text {dry }}+\Delta h_{\text {wet }}+\Delta h_{\text {iono }}+\right. \\
& \left.\Delta h_{s s b}+h_{\text {tides }}+h_{\text {atm }}+h_{R F O}\right)
\end{aligned}
$$

Dimana $\mathrm{H}$ merupakan altitude $(\mathrm{m}), \hat{R}$ adalah jarak observasi (m), MSS adalah mean sea surface $(\mathrm{m}), \Delta R G e o_{C o r r}$ adalah koreksi jarak dan geofisis $(m)$.

Tahap kedua adalah melakukan intercallibrated atau menghilangkan bias antar satelit. Data antar satelit akan memiliki tandem mission (bertampalan pada waktu yang sama) yaitu cycle awal dan akhir misi. Pada pertampalan tersebut akan terdapat bias karena masing masing satelit memiliki koreksi instrumen dan model sendiri. Hal pertama yang diakukan adalah menghitung rata - rata SLA percycle masingmasing satelit dengan membobotkannya berdasar latitude. Selanjutnya yang harus dilakukan adalah menghitung bias antar data tandem atau yang bertampalan dengan hitung perataaan kemudian dikoreksikan ke data SLA setiap cycle dengan persamaan (3) - (5). Misi yang dijadikan acuan atau tidak berubah adalah misi Topex/Poseidon
(Masters, 2012).

$$
\begin{aligned}
\text { CorrectedSLA(J1) }= & S L A(J 1)-\operatorname{bias}(J 1, T / P)(3) \\
\text { CorrectedSLA }(J 2)= & \operatorname{SLA}(J 2)-\operatorname{bias}(J 1, J 2)- \\
& \operatorname{bias}(J 1, T / P)
\end{aligned}
$$

$$
\text { CorrectedSLA(J3) }=S L A(J 3)-\operatorname{bias}(J 2, J 3)-
$$$$
\operatorname{bias}(J 1, J 2)-\operatorname{bias}(J 1, T / P)
$$

Selanjutnya tahap ketiga dari penelitian ini adalah dekomposisi data menggunakan perangkat lunak R. Data SLA penelitian ini merupakan data time series yang memiliki 3 komponen yaitu seasonal, trend, dan error (Dokumentov \& Hyndman, 2015). Metode yang digunakan untuk dekomposisi adalah LOESS /STL (A Seasonal-Trend Decomposition Procedure Based on Regression). Hasil yang akan digunakan untuk pengolahan selanjutnya adalah data trend. Setelah dekomposisi data proses selanjutnya adalah melakukan detrend data yaitu menghilangkan trend dari RAW data time series. Detren sendiri bertujuan untuk menghilangkan komponen yang menimbulkan distorisi pada proses anlisis time series dan membuat data time series menjadi stasioner.

Tahap keempat dari pengolahan data yaitu melakukan korelasi data detrend SLA dengan indeks ENSO. Indeks ENSO digunakan ada 3 yaitu MEI (Multivariate ENSO Index), SOI (Southern Oscillation Index), dan ONI (Oscillation Nino Index). MEI adalah indeks yang ditentukan dengan 6 variabel meteorologi utama yaitu tekanan permukaan laut, komponen zonal, meridional angin permukaan, suhu permukaan laut, suhu permukaan udara, dan total cloudiness fraction of the sky (Dahlman, 2016). Pada indeks SOI variabel yang digunakan adalah perbedaan tekanan udara di Darwin, Australia dan Tahiti (Sarachik \& Cane, 2010).Sedangkan untuk indeks ONI ditentukan dari rata-rata suhu permukaan laut khatulistiwa Pasifik atau Nino 3.4 region yang berada pada $5^{\circ} \mathrm{LU}-5^{\circ} \mathrm{LS}$ and $120^{\circ} \mathrm{BB}-$ $170^{\circ} \mathrm{BB}$ (Mazzarella, Giuliacci, \& Liritzis, 2010). Korelasi ini nantinya akan digunakan untuk melakukan analisa hubungan antara masing masing indeks ENSO MEI, SOI, dan ONI dengan SLA (Sea Level Anomaly) yang ada di perairan Indonesia selain itu juga dianalisa pengaruhnya fenomena ENSO terhadap iklim yang ada di Indonesia.

Tahap terakhir adalah gridding data sea level anomaly setiap cycle. Gridding dilakukan dengan ukuran $3^{\circ} \times 3^{\circ}$ dikarenakan satelit altimetri 
memiliki jarak lintasan pada ekuator sekitar 315 km (Dumont, Rosmorduc, Carrere, Bronner, \& Picot, 2016). Langkah ini dilakukan untuk mengetahui persebaran secara spasial pengaruh ENSO di perairan Indonesia. Setelah gridding, data dikonversikan menjadi (.txt). Data kemudian dikoreksi dengan bias, juga dekomposisi, detren dan dihitung korelasi sea level anomaly setiap titik dengan indeks ENSO. Untuk menampilkan hasil korelasi secara spasial maka dilakukan plotting dalam perangkat lunak ArcMap.

\section{HASIL DAN PEMBAHASAN}

\section{Perhitungan Sea Level Anomaly}

Pada tahap awal bagian yang penting adalah menentukan koreksi yang digunakan untuk pengolahan SLA. Dalam data RADS terdapat banyak model koreksi yang dapat digunakan menyesuikan tujuan pengolahan. Koreksi yang digunakan pada penelitian ini sebagai berikut.

Tabel 1. Koreksi Pengolahan SLA

\begin{tabular}{|c|c|c|c|c|}
\hline Parameter & $T / P$ & Jason-1 & Jason-2 & Jason-3 \\
\hline DTC & ERA-Interim & ERA-Interim & ERA-Interim & ERA-Interim \\
\hline $\begin{array}{l}\text { WTC } \\
\text { lonosfer }\end{array}$ & $\begin{array}{l}\text { ERA-Interim } \\
\text { smoothed } \\
\text { dual } \\
\text { frequency }\end{array}$ & $\begin{array}{l}\text { ERA-Interim } \\
\text { smoothed } \\
\text { dual } \\
\text { frequency }\end{array}$ & $\begin{array}{l}\text { ERA-Interim } \\
\text { smoothed } \\
\text { dual } \\
\text { frequency }\end{array}$ & $\begin{array}{l}\text { ERA-Interim } \\
\text { smoothed } \\
\text { dual } \\
\text { frequency }\end{array}$ \\
\hline SSB & $\begin{array}{l}\text { TOPEX_A : } \\
\text { BM4 } \\
\text { TOPEX_B : } \\
\text { NP-CLS } \\
\text { Poseidon : } \\
\text { BM4 }\end{array}$ & Tran2012 & Tran2012 & Tran2012 \\
\hline DAC & $\begin{array}{l}\text { local mean } \\
\text { of MOG2D }\end{array}$ & $\begin{array}{l}\text { local mean } \\
\text { of MOG2D }\end{array}$ & $\begin{array}{l}\text { local mean } \\
\text { of } \mathrm{MOG} 2 \mathrm{D}\end{array}$ & $\begin{array}{l}\text { local } \\
\text { mean of } \\
\text { MOG2D }\end{array}$ \\
\hline $\begin{array}{l}\text { Ocean } \\
\text { Tides }\end{array}$ & GOT4.10 & GOT4.10 & GOT4.10 & GOT4.10 \\
\hline $\begin{array}{l}\text { Load } \\
\text { Tides }\end{array}$ & GOT4.10 & GOT4.10 & GOT4.10 & GOT4.10 \\
\hline MSS & CNES-CLS11 & CNES-CLS11 & CNES-CLS11 & $\begin{array}{l}\text { CNES- } \\
\text { CLS11 }\end{array}$ \\
\hline
\end{tabular}

Data RADS berformat .nc dibaca di MATLAB kemudian diolah dengan hasil akhir nilai SLA perpass. Output dari proses ini adalah file .txt yang berisi cycle, pass, waktu, SSH, dan SLA yang sudah bereferensi MSS serta terkoreksi dari kesalahan jarak dan geofisis.

\section{Hasil Intercalibrated}

Hasil perhitungan rata -rata percycle masingmasing satelit digabungkan kemudian ditampilkan dalam grafik time series sebagai berikut.

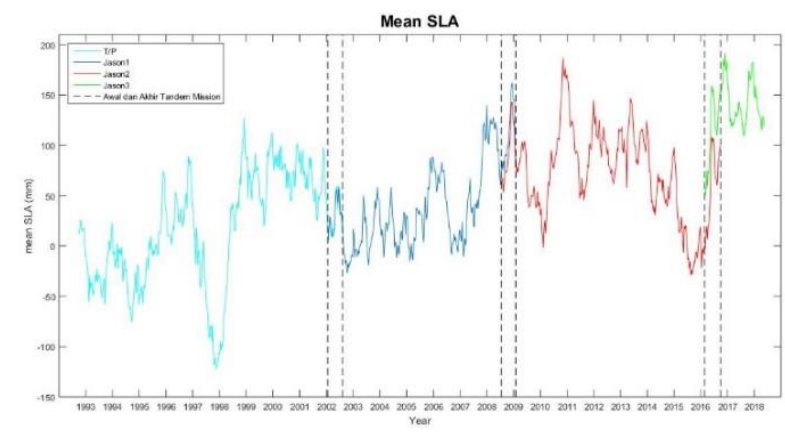

Gambar 2. Tandem Misi antar Satelit Altimetri

Garis warna biru muda menunjukkan SLA dari misi Topex/Poseidon, garis biru tua menunjukkan SLA Jason-1, garis merah menunjukkan SLA Jason-2, dan garis hijau menunjukkan SLA Jason-3. Pada Gambar 2 terlihat bahwa terdapat nilai SLA pada awal dan akhir cycle yang mengalami tandem atau bertampalan. Tandem misi terjadi karena dua satelit mengambil data secara berdampingan (depan-belakang) melewati jalur yang sama. Namun di bagian yang bertampalan tersebut terdapat jarak / selisih antar SLA yang seharusnya nilainya sama. Selisih atau perbedaan nilai ini disebabkan karena antara satelit Topex/Poseidon dengan Jason series sudah berbeda alat/ sensor dan perbedaan antar satelit Jason series terjadi karena terdapat sistematic error. Karena terdapat cycle yang mengalami tandem maka dihitung biasnya. Sebelum dihitung biasnya perlu didata terlebih dahulu cycle yang bertampalan dilihat dari waktu hasil pegolahan SLA.

Cycle yang bertampalan antara misi T/P dengan Jason-1 adalah cycle 344-364 dan cycle 1-21. Pada Jason-1 dan Jason-2 yang bertampalan adalah cycle 240-260 dan cycle 1-21. Tandem pada Jason-2 dan Jason-3 adalah cycle 281-303 dan cycle 1-23. Setelah diketahui rentang cycle yang bertampalan kemudian dihitung biasnya dengan hitung perataan. Hasil perhitungan mendapatkan nilai bias T/P dengan Jason-1 sebesar 0,619 mm, nilai bias Jason1 dengan Jason-2 sebesar $-18,160 \mathrm{~mm}$, sedangkan nilai bias Jason-2 dengan Jason-3 sebesar 50,9 mm. Setelah mendapatkan bias data RAW SLA dikoreksikan dengan bias merujuk pada persamaan (3) - (5). Hasil filtering cycle yang bertampalan dan tekoreksi dari bias dilihat pada Gambar 3,4,dan 5 . 


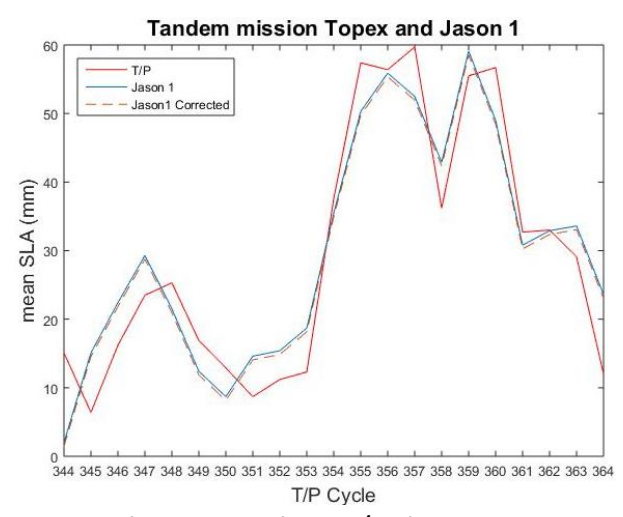

Gambar 3. Tandem T/P dan Jason-1

Gambar 3 menunujukkan grafik antara misi Topex/Poseidon dengan Jason-1. Data T/P ditunjukkan dengan garis biru, data Jason-1 warna hitam, dan garis putus-putus menunjukkan nilai cycle Jason-1 yang sudah terkoreksi.

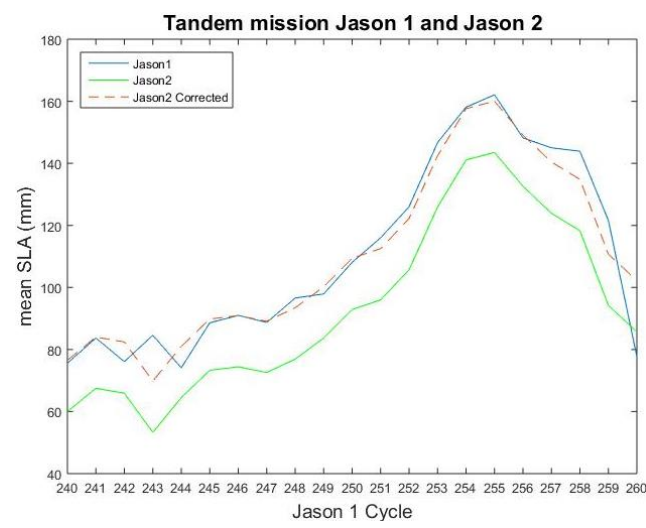

Gambar 4. Tandem Jason-1 dan Jason-2

Gambar 4 menunjukkan grafik antara misi Jason-1 dan Jason-2 yang bertampalan. Garis warna biru menunjukkan data Jason-1, warna hijau menunjukkan data Jason-2 sedangkan garis putus-putus menunjukkan hasil koreksi data Jason-2. Gambar 5 juga menunjukkan grafik tandem antara misi Jason-2 dengan Jason-3. Warna ungu menunjukkan data Jason-3, warna biru data Jason-2, dan gari putus-putus merupakan nilai jason-3 terkoreksi.

Dari hasil perhitungan SLA setela dikoreksi nilai rata-rata SLA percycle yang tertinggi terdapat pada cycle 86 Jason-2 sebesar 204,202 mm dan nilai rata-rata SLA terendah terdapat pada cycle 191 Topex/Poseidon sebesar $-121,600 \mathrm{~mm}$.

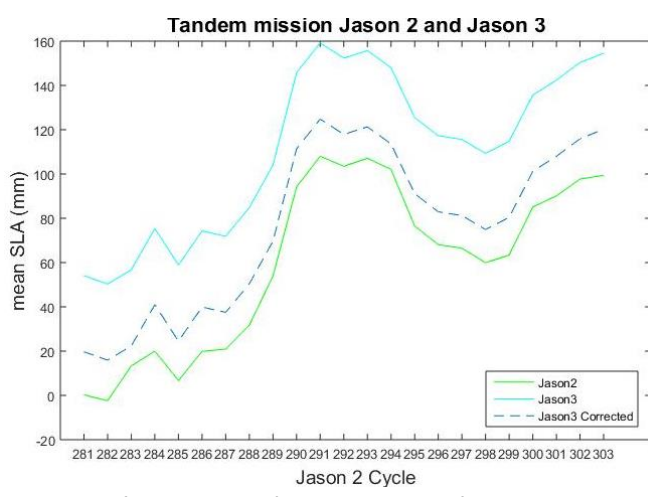

Gambar 5. Tandem Jason-2 dan Jason-3

\section{Hasil Dekomposisi dan Detrend}

Hasil dari proses dekomposisi nilai SLA terdapat 3 komponen yaitu seasonal, trend, dan Error serta RAW data. Grafik seasonal memiliki pola yang sama dan teratur. Sedangkan pada grafik trend menunjukkan nilai / pola yang meningkat. Untuk grafik remainder/error menunjukkan pola yang tidak teratur. Dalam grafik dibawah ini semua satuannya adalah $\mathrm{mm}$.

Untuk proses selanjutnya data yang digunakan adalah nilai trend. Selanjutnya dilakukan proses detren. Detren dilakukan dengan menghilangkan nilai trend linier pada RAW data dan hasilnya tampak pada Gambar 6.

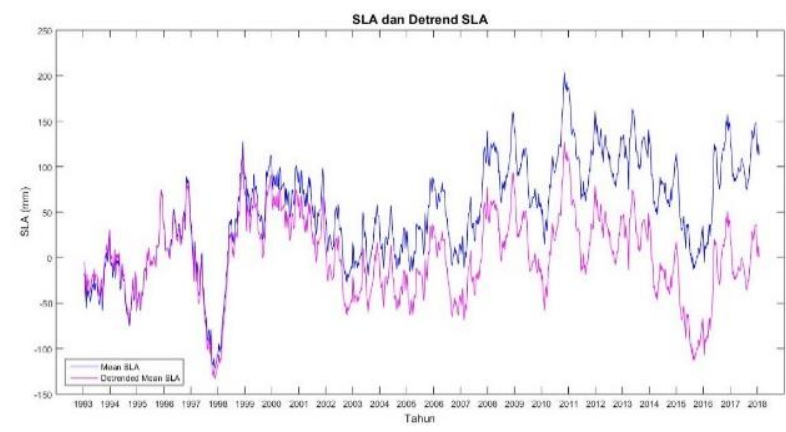

Gambar 6. Grafik SLA dan Detrend SLA

Trend dihilangkan karena dianggap akan menjadi menjadi nilai distorsi jika dilakukan proses korelasi. Garis biru menunjukkan data RAW SLA sedangkan grafik detrend ditunjukkan dengan garis ungu. Hasil grafik detren menunjukkan tidak adanya pola yang meningkat pada data time series.

\section{Korelasi SLA dengan indeks ENSO}

Sebelum dikorelasikan, nilai detrend SLA dikelompokkan terlebih dahulu sesuai dengan data indek ENSO yang tersedia. Untuk SOI nilai indeks berupa data setiap 1 bulan maka SLA harus dijadikan setiap bulan agar diketahui nilai korelasinya. Berbeda dengan SOI, MEI datanya adalah data 
"sliding bi-monhtly season" atau indeks rata-rata 2 bulan berturut-turut. Begitu juga dengan ONI datanya adalah rata-rata setiap 3 bulan, maka nilai detren perlu dikelompokkan tiap 2 bulan dan 3 bulan.

Hasil korelasi yang didapatkan dari perhitungan adalah sebagai berikut. Korelasi SLA dengan SOI menunjukkan nilai 0,6985 maka dapat dianalisa bahwa indeks SOI kuat pengaruhnya terhadap nilai SLA. Jika nilai SOI tinggi maka nilai SLA akan berbanding lurus atau tinggi juga. Untuk korelasi MEI dengan SLA adalah -0,7984 maka tingkat hubungan 2 variabel tersebut adalah kuat, namun berbanding terbalik. Jika nilai MEI naik maka nilai SLA akan turun. Nilai korelasi SLA dengan ONI adalah $-0,8583$ maka tingkat hubungannya sangat kuat dan berbanding terbalik. Pada Gambar 7, 9, dan 10 menunjukkan hubungan antara nilai indeks ENSO dengan nilai SLA di perairan Indonesia. Klasifikasi hubungan korelasi ada 5 yaitu sangat kuat $(\rho>0,8)$, kuat $(0,6<$ $\rho<0,799)$, sedang $(0,4<\rho<0,599)$, rendah $(0,2<$ $\rho<0,399)$, dan sangat rendah $(\rho<0,2)$ (Evans, 1996).

Garis merah menunjukkan nilai SLA sedangkan area yang diwarna menunjukkan indeks ENSO.

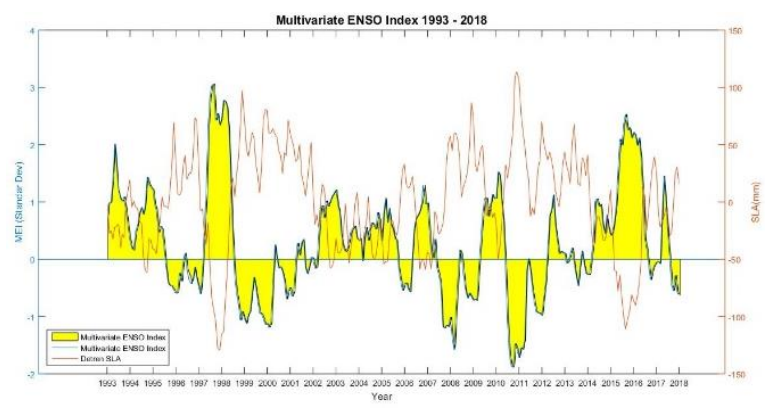

Gambar 7. Detrend SLA dan MEI

Hasil korelasi antara detren SLA dengan $\mathrm{MEI}$ adalah negatif dan berintensitas tinggi. Jika nilai MEI kecil maka nilai SLA akan tinggi. Parameter penentu MEI adalah tekanan atmosfer dan suhu permukaan laut. Ketika El Nino nilai MEI adalah positif, di Pasifik bagian timur tekanan atmosfer turun dan suhu permukaan laut meningkat sedangkan di Pasifik barat (Indonesia) suhu permukaan laut turun dan tekanan atmosfer meningkat jadi hal itu yang menyebabkan korelasi di Indonesia negatif. Dari perhitungan korelasi SLA setiap titik dengan MEI ditampilkan secara spasial pada gambar

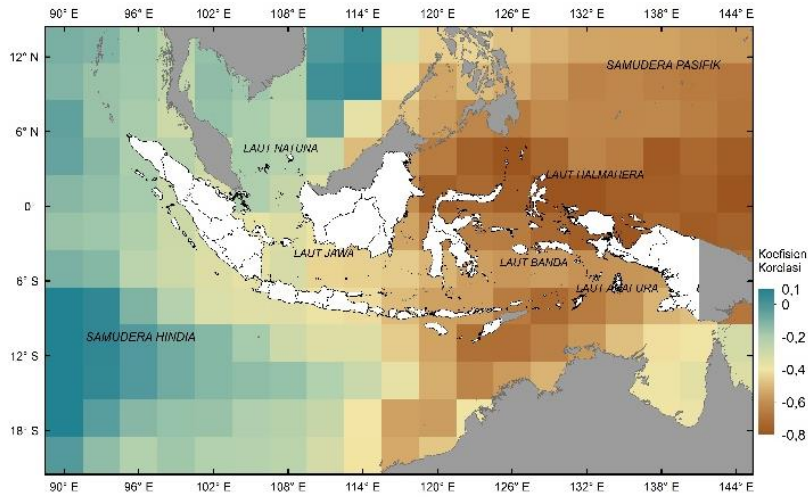

Gambar 8. Plotting Hasil Korelasi SLA dengan MEI

Penjelasan dari gambar 8 adalah wilayah dengan warna coklat memiliki korelasi kuat sedangkan yang berwarna hijau memiliki korelasi yang lemah. Korelasi tertinggi ada di Laut Halmahera, sedangkan wilayah dengan korelasi rendah ada di Laut Natuna, Laut Jawa bagian barat, dan perairan sekitar Sumatera.

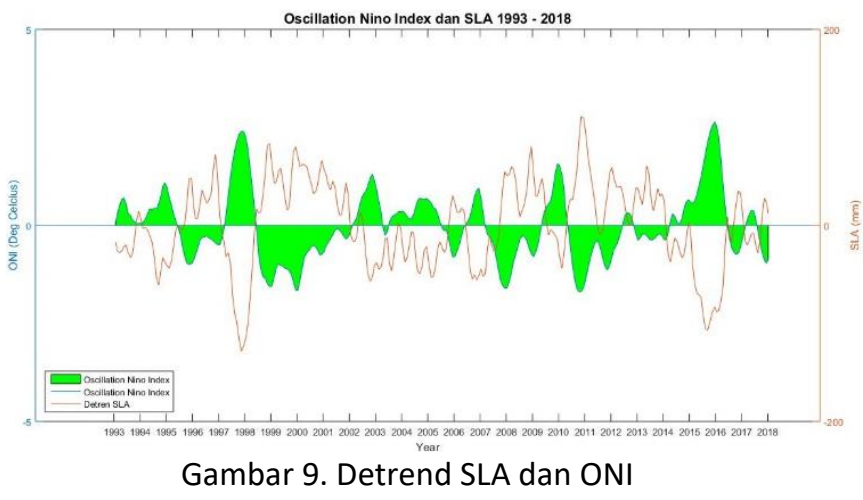

Nilai hubungan antara detren SLA dan ONI adalah negatif dan berintesitas kuat hal tersebut tampak pada Gambar 9, jika nilai ONI meningkat (dapat dikatan terjadi El Nino) maka nilai SLA di perairan Indonesia akan menurun. Hal tersebut terjadi karena nilai SST (Sea Surface Temperature) di Nino 3.4 atau daerah khatulistiwa tengah-timur Samudera Pasifik meningkat. Yang digunakan adalah Nino 3.4 karena indeks ini dibuat dengan tujuan untuk mengetahui perubahan SST antara region 3 dan 4, selain itu indeks ONI dari region ini memiliki respon yang paling baik terhadap suhu permukaan laut dibandingkan indeks ONI lainnya (Hanley, Borassa, O'Bren, Smith, \& Elizabeth R Spade, 2003) Kenaikan suhu permukaan laut pada perairan di bagian timur akan meningkatkan sea level di wilayah tersebut. 


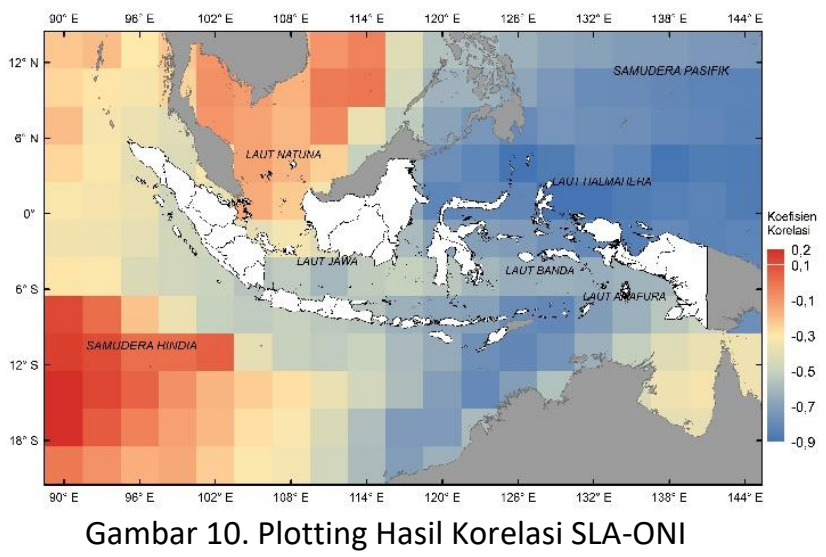

Penjelasan ari gambar 10 adalah wilayah dengan warna merah memiliki korelasi yang rendah sedangkan wilayah berwarna biru memiliki korelasi kuat.

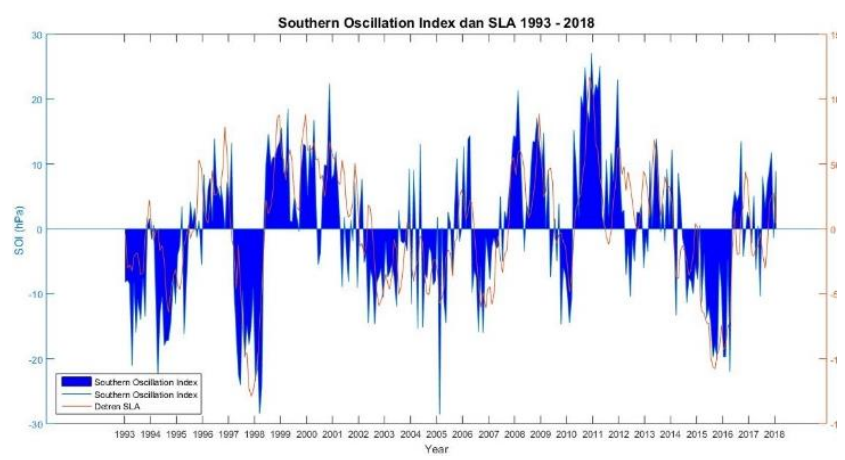

Gambar 11. Detrend SLA dan SOI

Berbeda dari indeks ENSO lainnya, nilai korelasi antara detren SLA dengan SOI positif dan berintensitas kuat. Hal tersebut menandakan jika nilai SOI meningkat maka nilai SLA di perairan Indonesia akan meningkat juga seperti pada Gambar 11. SOI dilihat dari variabel perbedaan tekanan atmosfer di permukaan laut wilayah Tahiti (Pasifik Timur) dan laut wilayah Darwin (Pasifik Barat). El Nino ditandai dengan nilai indeks SOI negstif sebaliknya La Nina ditandai ketika indeks SOI positif. Ketika El Nino, tekanan udara di Pasifik tengah-timur lebih rendah dibandingkan Pasifik barat sehingga tinggi muka laut di Pasifik barat menurun karena upwelling.

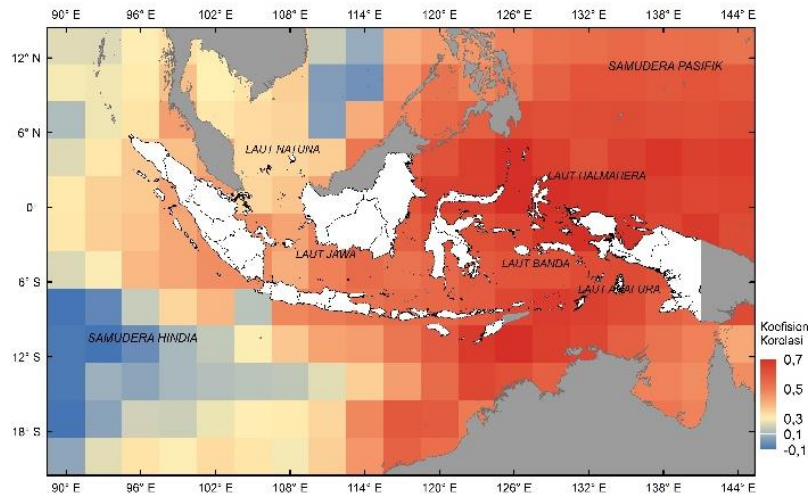

Gambar 12. Plotting Hasil Korelasi SLA-SOI

Penjelasan dari gambar 12 diatas adalah wilayah dengan korelasi kuat memiliki warna merah sedangkan wilayah dengan korelasi rendah berwarna biru. Dari ketiga hasil plotting diketahui bahwa wilayah Indonesia bagian barat memiliki korelasi yang rendah sedangkan wilayah Indonesia timur memiliki korelasi yang kuat. Wilayah dengan korelasi kuat ada di Laut Halmahera, Laut Sulawesi, Laut Banda, perairan utara Papua, dan periaran sekitar Nusa Tenggara. Sedagkan wilayah dengn korelasi sedang ada di Laut Jawa bagian timur, Laut Flores, dan Selat Makasar. Untuk wilayah dengan korelasi rendah ada di perairan sekitar Sumatera dan Laut Natuna.

\section{KESIMPULAN}

Berdasarkan data RADS, pada penlitian ini dihitung korelasi sea level anomaly dari data altimetri dengan indeks ENSO di Perairan Indonesia, maka kesimpulannya adalah sebagai berikut.

1) Hasil rata-rata sea level anomaly di perairan indonesia adalah $50,259 \mathrm{~mm}$ dengan nilai maksimum 204,202 mm pada cycle 86 Jason-2 dan nilai minimum -121,600 mm pada cycle 191 Topex/Poseidon.

2) Koefisien korelasi sea level anomaly dengan multivariate enso index dan oscillation nino index memiliki hubungan kuat dan negatif. Sedangkan korelasi sea level anomaly dengan southern enso index bernilai kuat dan positif. Halitu terjadi karena SOI dihitung dari parameter perbedaan tekanan atmosfer di Tahiti dan Darwin. Ketika keadaan normal tekanan atmosfer di Pasifik barat lebih rendah dari Pasifik timur.

3) Wilayah dengan korelasi sangat kat ada di Indonesia bagian timur yaitu laut Halmahera, Laut Sulawesi, Laut Arafura, Laut Banda, dan 
Laut sekitar Nusa Tenggara Timur. Seabiknya pada Indonesia bagian barat memiliki korleasi rendah, yaitu laut Natuna, perairan sekitar Sumatera, dan perairan Jawa bagian barat. Perairan sekitar Jawa Timur, Bali, Laut Flores, Sealat Makasar memiliki nilai korelasi sedang.

\section{DAFTAR PUSTAKA}

Dahlman, L. (2016). Climate Variability Oceanic NIno Index. Diambil 21 Maret 2018, dari https://www.climate.gov/newsfeatures/understan1 ding-climate/climatevariability-oceanic-niño-index

Dokumentov, A., \& Hyndman, R. J. (2015). STR: A Seasonal-Trend Decomposition Procedure Based on Regression STR: A Seasonal-Trend Decomposition Procedure Based on Regression.

Dumont, J. P., Rosmorduc, V., Carrere, L., Bronner, E., \& Picot, N. (2016). Jason-3 Products Handbook.

Evans, J. D. (1996). Straightforward Statistic for the Behavioral Science. Pasific Grove, CA:Brook/Core Publishing.

Handoko, E. Y., Fernandes, M. J., \& Lázaro, C. (2017). Assessment of altimetric range and geophysical corrections and mean sea surface models-Impacts on sea level variability around the Indonesian seas. Remote Sensing, 9(2). https://doi.org/10.3390/rs9020102

Hanley, D. E., Borassa, M. A., O'Bren, J. J., Smith, S. R., \& Elizabeth R Spade. (2003). A Quantitative Evaluation of ENSO Indices. Journal of Climate, 16, 1249-1258.

Masters, D. (2012). Comparison of Global Mean Sea Level Time Series from TOPEX/Poseidon, Jason-1, and Jason-2. Marine Geodesy, 20-41.

Mazzarella, A., Giuliacci, A., \& Liritzis, I. (2010). On the 60-month cycle of multivariate ENSO index. Springer, 23-27. https://doi.org/10.1007/s00704-009-0159-0

Qian, J. H., Robertson, A. W., \& Moron, V. (2010). Interaction Among ENSO, the Monsoon, and Diurnal Cycle in Rainfall Variability Over JAva, Indonesia. Journal of the Atmospheric Sciences, (67), 3509-3524.

Rejeki, H. A., Munasik, \& Kunarso. (2017). The Effect of ENSO to the Variability of Sea Surface Height in Western Pacific Ocean and Eastern Indian Ocean and its Connectivity to the Indonesia Throughflow (ITF). IOP Conference Series: Earth and Enviromental Science 55. https://doi.org/10.1088/1742-

\section{6/755/1/011001}

Sarachik, E. S., \& Cane, M. A. (2010). The El NiñoSouthern Oscillation Phenomenon. The Cambridge University Press. 